\title{
Pemberdayaan Pokdakan Mina Usaha Rumbai Bukit dalam pengolahan mie kaya nutrisi untuk meningkatkan imunitas tubuh di masa pandemi
}

\author{
Dian Iriani*, N Ira Sari, Bustari Hasan, \& Tjipto Leksono \\ Fakultas Perikanan dan Ilmu Kelautan, Universitas Riau \\ *dian.iriani@lecturer.unri.ac.id
}

\begin{abstract}
Abstrak. Pandemi Covid-19 adalah jenis penyakit disebabkan oleh virus SARS-CoV-2 atau virus Corona yang menyebabkan gangguan kesehatan, mulai dari flu, hingga infeksi paru-paru. Untuk menjaga imunitas tubuh terhadap Covid-19 maka diperlukan bahan pangan yang bernutrisi seperti ikan patin. Ikan patin merupakan jenis ikan yang bernilai ekonomis dimana selain mudah dibudidayakan juga mengandung zat gizi yang sangat tinggi, yaitu protein $17.63 \%$, abu $1.07 \%$, lemak 2.23\% BK, lemak $12.14 \%$, kadar air $81.57 \%$, asam lemak jenuh $47.15 \%$, MUFA $40.41 \%$, PUFA $12.45 \%$. Oleh karena itu sangat baik untuk dikonsumsi di masa pandemi. Namun tidak semua orang suka mengkonsumsinya dalam keadaan segar, untuk itu dilakukan pengolahan dalam bentuk mie ikan patin. Untuk meningkatkan kesukaan konsumen terhadap mie patin, maka ditambahkan pewarna alami alami dari bayam dan wortel yang memberikan warna hijau dan orange, sehingga dihasilkan mie kaya nutrisi dengan warna yang lebih menarik. Kegiatan ini dilakukan dengan menerapkan protokol kesehatan terhadap 10 orang peserta yang bertujuan untuk memberikan wawasan dan pengetahuan praktis kepada kelompok masyarakat Kelurahan Rumbai Bukit Kecamatan Rumbai tentang teknik pengolahan mie ikan sehingga dapat meningkatkan pendapatan keluarga terutama pada masa pandemi. Antusiasme peserta yang sangat tinggi sehingga kegiatan berjalan dengan lancar. Dari hasil post-test didapatkan $100 \%$ peserta telah memahami teknik diversifikasi pengolahan hasil perikanan.
\end{abstract}

Kata kunci: mie kaya nutrisi, ikan Patin, pandemi, imunitas tubuh

\begin{abstract}
Pandemic in the form of Covid-19 is a new type of disease caused by SARS-CoV-2 virus or Corona virus which can cause health problems in the form of respiratory system disorders, starting from mild symptoms such as flu, to lung infections, such as pneumonia. To maintain body immunity against Covid 19, nutritious food ingredients in the form of catfish are needed. Catfish is a type of fish that has a high economic value, where apart from being easy to cultivate, this fish also contains very high nutrients, namely $17.63 \%$ protein, $1.07 \%$ ash, $2.23 \%$ fat (DW), $12.14 \%$, fat (WW), moisture content $81.57 \%, 47.15 \%$ saturated fatty acids, MUFA $40.41 \%$, PUFA $12.45 \%$. Therefore, it is very good for consumption during a pandemic. However, not everyone likes to consume catfish fresh, so it is processed in the form of catfish noodles. To increase consumer preference for catfish noodles, natural dyes from spinach and carrots are added which will give green and orange colors and attract consumers, so that ultimately nutrient-rich noodles are produced. This activity was carried out with 10 participants by implementing health protocols that aim to provide insight and practical knowledge to community groups in Rumbai Bukit Village, Rumbai District about fish noodle processing techniques so that they can increase family income, especially during the pandemic. The enthusiasm of the participants was very high so that the activity went smoothly. From the post-test results, it was found that $100 \%$ of the participants had understood the diversification techniques of fishery product processing
\end{abstract}

Keywords: nutrient-rich noodles, Catfish, pandemic, body immunity

To cite this article: Iriani, D., N. I. Sari., B. Hasan., \& T. Leksono. 2020. Pemberdayaan Pokdakan Mina Usaha Rumbai Bukit dalam pengolahan mie kaya nutrisi untuk meningkatkan imunitas tubuh di masa pandemi. Unri Conference Series: Community Engagement 2: 286-291. https://doi.org/10.31258/unricsce.2.286-291

(C) 2020 Authors

Peer-review under responsibility of the organizing committee of Seminar Nasional Pemberdayaan Masyarakat 2020 


\section{PENDAHULUAN}

Makanan sehat merupakan makanan yang sangat diperlukan oleh tubuh, karena dapat menjaga kesehatan dan imunitas tubuh. Sangat disayangkan sekali jika anak-anak sebagai penerus bangsa mendapatkan masalah kesehatan yang berasal dari makanan dan minuman yang dikonsumsinya. Terutama di masa pandemi Covid19 ini kita harus dapat menjaga imun tubuh kita sehingga dapat memeranginya, Covid atau Coronavirus Disease adalah penyakit yang memiliki gejala demam, batuk kering, serta kesulitan bernapas yang dapat mengakibatkan pasien terkena pneumonia dan kegagalan multi organ. Penyakit ini dapat ditularkan melalui percikan dari saluran pernapasan saat batuk atau bersin. Salah satu cara untuk pencegahan penyakit ini selain daripada menjaga kebersihan dengan mencuci tangan, menggunakan masker, dan menjaga jarak adalah dengan memakan makanan yang mengandung protein yang tinggi seperti ikan.

Ikan patin merupakan salah satu jenis ikan yang memiliki nilai ekonomis yang tinggi dimana selain mudah dibudidayakan ikan ini juga mengandung nilai gizi yang sangat tinggi, dimana menurut Viji et al., 2015 bahwa ikan patin mengandung kadar protein $17.63 \%$, abu 1.07\%, dan Domiszewski et al., (2011) menambahkan bahwa ikan patin juga mengandung lemak $2.23 \% \mathrm{BK}, 12.14 \% \mathrm{BB}$, kadar air $81.57 \%$, Asam lemak jenuh $47.15 \%$, MUFA $40.41 \%$, PUFA $12.45 \%$, EPA+DHA $16.47 \%$ mg/100 gr. Protein pada ikan tersusun dari asamasam amino yang dibutuhkan tubuh untuk pertumbuhan. Selain itu, protein ikan mudah dicerna dan diserap oleh tubuh. Protein merupakan komponen penting dari setiap sel dalam tubuh. karena dapat membangun, memperkuat, atau mengganti jaringan tubuh. Selain itu protein juga membuat enzim yang berfungsi memfasilitasi reaksi biokimia dan metabolisme tubuh sehingga dapat membuat antibodi untuk sistem kekebalan tubuh, sehingga sangat dibutuhkan di masa pandemic Covid-19 ini.

Mie merupakan produk makanan yang diminati oleh segala jenis usia, baik anak-anak maupun dewasa yang biasanya dibuat dari bahan baku tepung terigu atau tepung tapioka, yang dicampurkan dengan bahan lain untuk meningkatkan mutu mie tersebut. Terdapat beberapa jenis mie, diantaranya ada mie kering, mie basah, dan mie instan. Mie basah merupakan mie yang sudah direbus langsung dikonsumsi, dan mie basah ini merupakan mie yang sudah populer dan disukai oleh masyarakat Indonesia.

Nilai gizi utama dari mie basah adalah karbohidrat, jumlah karbohidrat dalam $100 \mathrm{~g}$ mie basah adalah 14\%, protein $0,6 \%$, lemak 3,3\%, vitamin 0\% dan kandungan air yang dapat mencapai $80 \mathrm{~g}$ (Purnawijayanti, 2009). Pada mie basah kandungan karbohidratnya tinggi, sedangkan kandungan protein, dan vitaminnya rendah (Mualim et al., 2013). Maka dari itu perlu dilakukan fortifikasi pada mie basah, salah satunya adalah dengan menambahkan daging ikan patin sebagai sumber protein. Menurut hasil penelitian Candra dan Rahmawati (2018), semakin banyak daging ikan yang ditambahkan pada adonan mie, maka akan menghasilkan warna mie basah yang semakin gelap. Untuk mengatasi masalah tersebut salah satu cara yang dapat dilakukan adalah dengan penambahan pewarna alami dari bayam dan wortel, sehingga mie yang dihasilkan kaya protein dengan warna yang menarik.

Berdasarkan penelitian yang telah kami lakukan, adapun kandungan gizi dari mie basah yang difortifikasi daging ikan patin dan sayuran bayam dan wortel yaitu protein berkisar 12,68\%, kadar air $63,62 \%$, ALT 21,3 x 103 koloni/gram, dan E Coli <3 APM (Ridwan, 2019). Kegiatan pengabdian kepada masyarakat ini dilaksanakan di Pokdakan Mina Usaha Rumbai Bukit dengan menerapkan protokol kesehatan. Mengingat bahwa Pokdakan ini memiliki Budidaya ikan patin yang cukup banyak yang sedang dikembangkan.Melalui kegiatan pengabdian kepada masyarakat ini diharapkan masyarakat petani ikan, khususnya isteri kelompok Tani Mina Usaha Kelurahan Rumbai Bukit Kecamatan Rumbai Pekanbaru, dapat melakukan kegiatan produktif yang dapat menunjang kesejahteraan mereka dan dapat meningkatkan imunitas tubuh di masa pandemi Covid-19. Disamping itu, apabila teknik pengolahan mie ikan ini diterima dan dikembangkan oleh masyarakat Kelurahan Rumbai Bukit, bahkan dapat diperluaskan di wilayah seluruh Kota Pekanbaru, maka diharapkan produk mie ikan dapat menjadi salah satu produk unggulan berbasis ikan di daerah ini.

\section{METODE PENERAPAN}

Adapun metode yang digunakan dalam kegiatan pengabdian kepada masyarakat ini adalah metode praktek langsung pengolahan mie basah aneka warna kaya nutrisi sebagai makanan sehat untuk menunjang imunitas di masa pandemi Covid-19 pada 10 orang peserta yang tergabung dalam Kelompok Tani Mina Usaha Rumbai Bukit kelurahan Rumbai Kota Pekanbaru, selain itu juga diikuti oleh 10 orang Mahasiswa Kukerta Integrasi Pengabdian Masyarakat. Dalam pelaksanaannya peserta dibagi menjadi 3 kelompok (1 kelompok ada 3-4 orang), dimana masing-masing kelompok membuat mie dengan warna yang berbeda, yaitu mie tanpa warna, mie warna hijau dari bayam dan mie orange dari wortel. 


\section{Teknik pengumpulan data}

Data yang dikumpulkan berupa data primer dan data sekunder. Data primer diperoleh dari wawancara langsung dari sumber yang terkait yakni Lurah, Ketua Pokdakan dan masyarakat yang merupakan peserta yang terlibat langsung dalam kegiatan pengabdian ini. Data sekunder merupakan data penunjang yang diperoleh dari sumber bacaan yang bersifat tidak langsung yang terkait dengan pengolahan mie basah. Data yang didapat dianalisis secara deskriptif dan digambarkan secara sistematis mengenai kegiatan pengabdian kepada masyarakat yang dilakukan tentang pelatihan mie kaya nutrisi di Kelurahan Rumbai Bukit Pekanbaru yang berjarak $\pm 21,9 \mathrm{~km}$ dari kampus Universitas Riau Panam Pekanbaru. Kegiatan pengabdian kepada masyarakat ini dilaksanakan selama 3 bulan, yaitu dari bulan Juni, Juli dan Agustus 2020, dengan beberapa tahap yaitu tahap persiapan (penetapan daerah dan penyeleksian calon peserta) dan tahap pembelajaran (pelatihan), serta tahap evaluasi. Berdasarkan pre-test dan post-test yang telah dilakukan dapat dilihat bahwa kegiatan pengabdian ini berdampak positif sekali bagi para peserta, dimana terjadi peningkatan pengetahuan hingga $100 \%$. Secara jelas tingkat keberhasilan atau ketercapaian kegiatan pengabdian tersebut dapat dilihat pada tabel 1.

Tabel 1. Tingkat keberhasilan kegiatan

No. Pre-test Post-test

$1 \quad$ Peserta sulit memulai usaha pengembangan produk hasil perikanan

2 Pengetahuan peserta tentang diversifikasi produk hasil perikanan terbatas

3 Peserta belum mengetahui teknik pengolahan mie kaya nutrisi

$4 \quad$ Peserta belum mengetahui bentuk kreativitas produk

5 Produk olahan ikan berorientasi hanya untuk konsumsi pribadi

$6 \quad$ Peserta belum mengetahui tentang teknik pemasaran dan promosi produk olahan perikanan Peserta mulai bisa mengembangkan usaha
produk hasil perikanan

Pengetahuan peserta tentang diversifikasi produk hasil perikanan sudah banyak

Peserta sudah mengetahui teknik pengolahan mie kaya nutrisi

Peserta sudah mengetahui bentuk kreativitas produk

Produk olahan ikan berorientasi untuk komersial

Peserta sudah mengetahui tentang teknik pemasaran dan promosi produk olahan perikanan

Dengan keberhasilan berupa ketercapaian kegiatan pengabdian mulai dari pengembangan produk hingga sudah mengetahui teknik pemasaran dan promosi produk, sehingga peserta telah dapat meningkatkan kreativitas produk yang dapat meningkatkan nilai tambah produk dan akhirnya akan meningkatkan pendapatan perekonomian keluarga.

\section{HASIL DAN KETERCAPAIAN SASARAN}

Sebagai makanan alternatif pengganti nasi, mie sangat populer dikalangan masyarakat karena selain harganya murah, cara pengolahan dan penyajiannya pun juga mudah. Mie mengandung karbohidrat, yang menyumbang energi pada tubuh sehingga mi dapat dijadikan sebagai makanan pengganti nasi. Mie merupakan salah satu sumber pangan yang disukai oleh masyarakat, teksturnya yang lembut, rasanya yang enak, jika diberi kuah dengan dengan penambahan bumbu-bumbu maka akan menggugah selera konsumen apalagi dihidangkan dalam keadaan panas. Namun mie yang beredaran dipasaran hanya kaya akan karbohidrat dan rendah protein, maka untuk memberikan kandungan protein ditambahkan sumber protein hewani dari ikan, sehingga mie yang dihasilkan dapat meningkatkan sistem imunitas tubuh terhadap penyakit, karena ikan dapat menstimulasi 
sistem imun di dalam tubuh, sebab tubuh membutuhkan protein yang cukup serta suplai makanan yang bermutu. Selain kaya protein, ikan juga mengandung vitamin A yang berguna untuk membantu menyerang patogen asing yang masuk ke dalam tubuh, dan vitamin D pada ikan juga dapat menjaga kesehatan tulang dan gigi serta menjaga kesehatan sistem kekebalan tubuh, otak, dan sistem saraf.

Masa pandemi ini kita harus dapat menjaga imun tubuh kita sehingga dapat memerangi penyakit COVID - 19. Penyakit ini dapat ditularkan melalui percikan dari saluran pernapasan saat batuk atau bersin. Inilah salah satu alasan dimana para peserta pelatihan sangat antusias untuk mengikuti kegiatan pengabdian ini karena mereka berusaha untuk tetap sehat dengan mengkonsumsi makanan yang sehat dan bergizi. Proses pengolahan mie ikan patin aneka warna diawali dengan pengambilan daging ikan patin. Mengingat ikan patin merupakan salah satu jenis ikan yang sedang dibudidayakan didaerah ini. Sehingga luaran dari kegiatan ini terciptanya mie kaya nutrisi untuk meningkatkan imunitas tubuh di masa pandemi Covid-19. Peserta dapat menikmati langsung mie kaya nutrisi yang telah dibuat, serta melatih masyarakat di Kelurahan Rumbai Bukit dalam pembuatan mie ikan sehingga dapat meningkatkan skill//pengetahuan mereka tentang diversifikasi produk olahan perikanan.

\section{Prosedur pengambilan daging ikan patin}

Adapun langkah-langkah dalam pengambilan daging ikan patin (Gambar 1) yaitu ikan yang masih segar dibersihkan dengan cara dicuci, lalu daging ikan patin di fillet dan dibuang kulitnya, selanjutnya dihaluskan dan siap untuk diolah menjadi mie ikan kaya nutrisi.

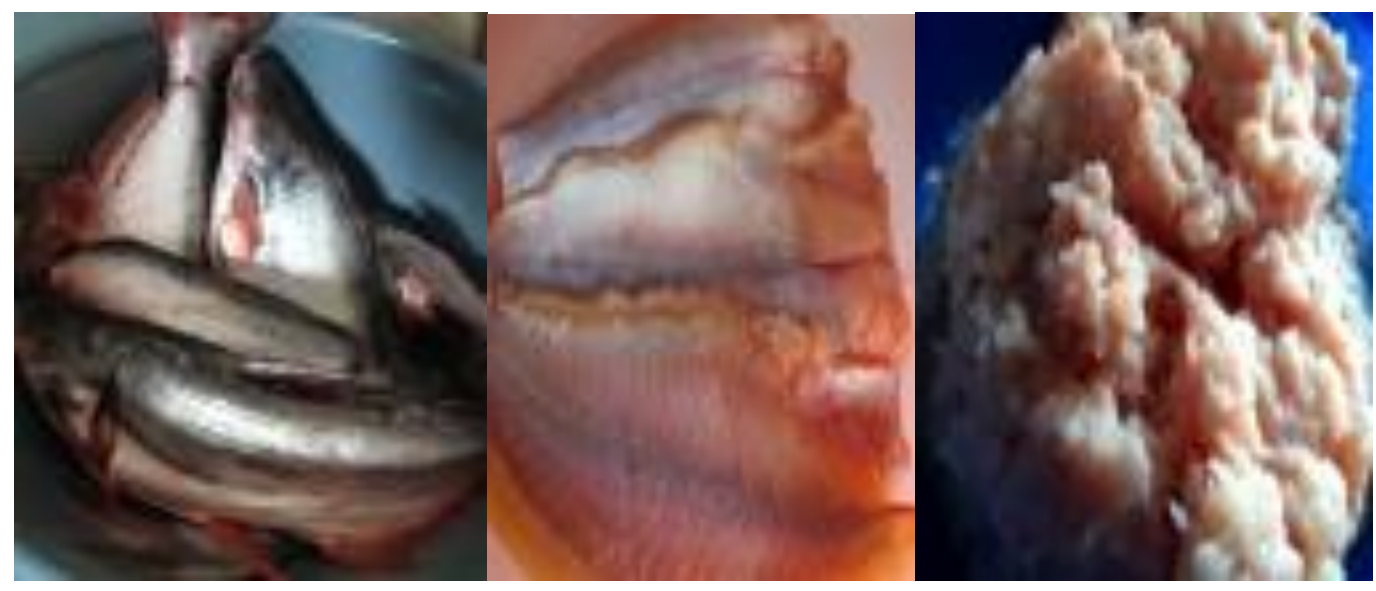

Gambar 1. Daging ikan patin

\section{Pembuatan mie ikan Patin}

Untuk mendapatkan mie ikan yang enak dan teksturnya bagus, maka komposisi bahan-bahan yang digunakan dapat dilihat pada tabel 2 dibawah ini, dimana mie basah ikan ini dibuat menjadi tiga bentuk (natural khas warna ikan patin) warna hijau dari bayam, dan warna orange dari wortel (Gambar 2).

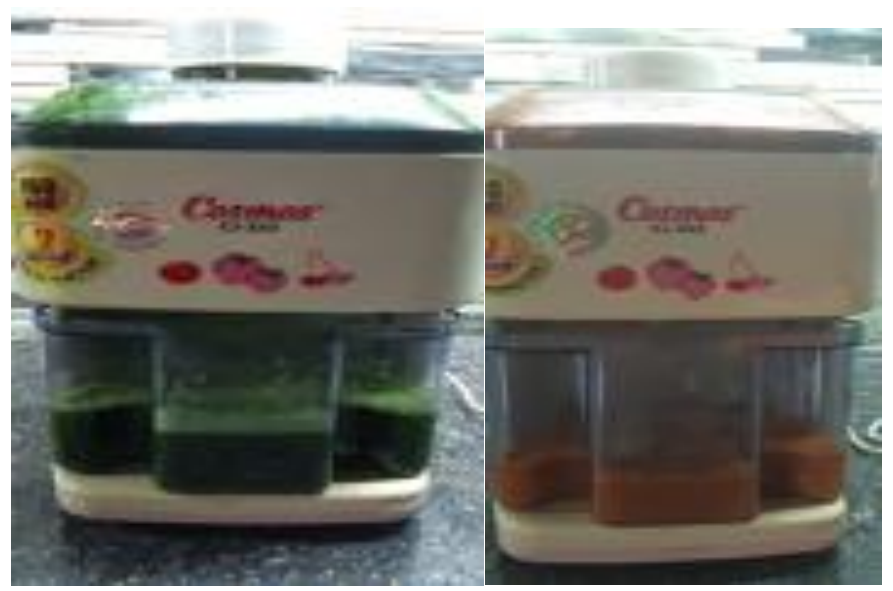

Gambar 2. Bayam dan Wortel sebagai pewarna alami 
Tabel 2. Komposisi bahan-bahan mie ikan

\begin{tabular}{cc}
\hline Bahan-bahan & Jumlah (gr) \\
\hline Daging Ikan (halus) & 150 \\
Tepung terigu & 1000 \\
Telur & 2 butir \\
Garam & 12 \\
Soda kue & 5 \\
Air & $200 \mathrm{ml}$ \\
Bayam* & $200 \mathrm{ml}$ \\
Wortel* & $200 \mathrm{ml}$ \\
\hline
\end{tabular}

\footnotetext{
*Pewarna alami
}

Sedangkan peralatan yang digunakan dalam pembuatan mie basah adalah: pisau, blender, mixer, sealer, baskom, cetakan mie, serbet, dandang, kompor, sendok, nampan, talenan, panci, dan timbangan. Untuk memberikan semangat kepada peserta, maka tim pengabdian memberikan bantuan berupa alat pencetak mie.

\section{Prosedur pengolahan mie ikan}

- Bahan-bahan ditimbang sesuai formulasi. Kemudian ke dalam bahan ditambahkan pewarna alami dari bayam dan wortel. Lalu diaduk sampai homogen

- Adonan yang telah homogen didiamkan \pm 15 menit lalu di press dengan ampia ketebalan $2 \mathrm{~mm}$

- Lembaran adonan yang telah di press kemudian dicetak menjadi untaian mie dengan menggunakan cetakan pembuat mie (ampia) dan dipotong sepanjang $15 \mathrm{~cm}$

- Untaian mie yang telah jadi ditaburi dengan tepung terigu agar tidak lengket satu sama lain

- Setelah itu dilakukan perebusan \pm 3 menit, sambil diaduk perlahan. Lalu angkat dan tiriskan

- Tahapan terakhir yaitu pemberian minyak goreng 1 sendok agar untaian mie terlihat mengkilat dan tidak lengket satu sama lain.

- Apabila belum ingin disajikan, mie basah dikemas dalam plastik HDPE (High Density Polyethylene) dan disimpan pada suhu dingin.

Untuk lebih jelasnya kegiatan pengolahan mie kaya nutrisi dapat dilihat pada gambar 3 berikut.

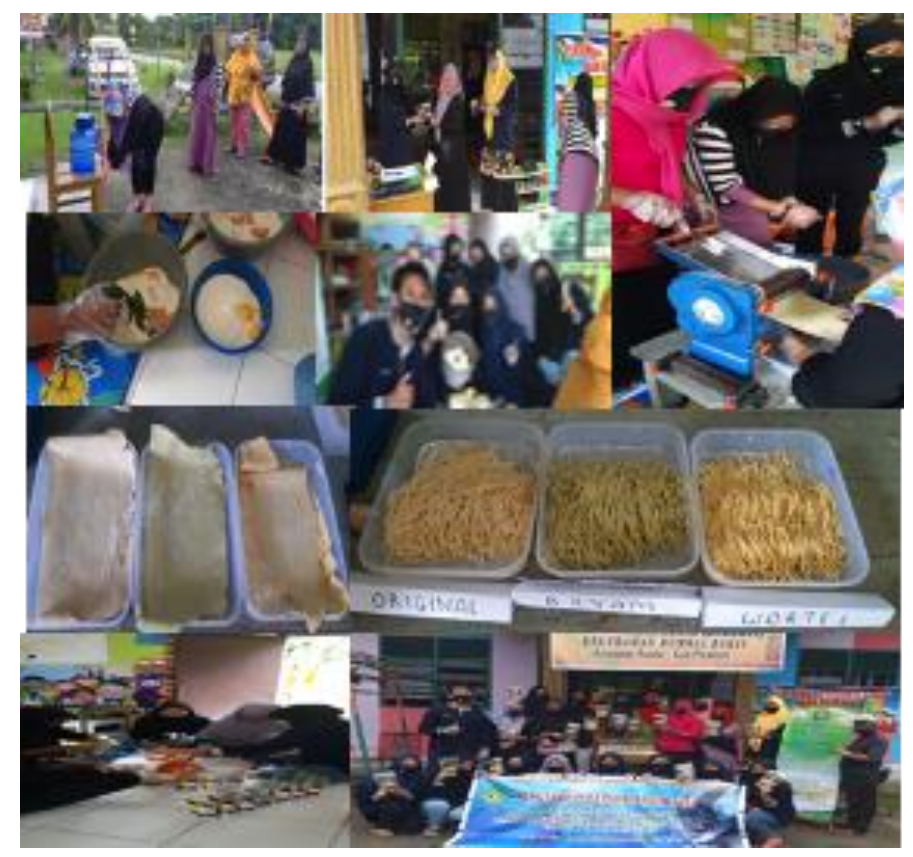

Gambar 3. Dokumentasi Kegiatan Pengabdian Kepada Masyarakat di Kelurahan Rumbai Bukit Kecamatan Rumbai, Pekanbaru 
Produk olahan mie kaya nutrisi yang telah jadi dimasukkan kedalam kemasan plastik Zipper standing pouch PP yang berukuran $14 \times 22 \times 0.1 \mathrm{~cm}$ yang sudah dilabel. Selain itu, mie kaya nutrisi dapat dikonsumsi langsung dengan saus, atau dinikmati seperti mie goreng atau mie rebus.

Salah satu keunggulan Kelurahan Rumbai Bukit adalah tersedianya bahan baku ikan patin dalam jumlah yang cukup banyak karena adanya mitra yang sedang menggalakkan budidaya ikan patin serta tersedianya bayam dan wortel, sehingga usaha diversifikasi produk mie dengan fortifikasi ikan patin, bayam dan wortel dapat berjalan lancar. Disamping keunggulan tersebut, terdapat kelemahan dimana belum tersedianya ruangan khusus dan minimnya peralatan untuk usaha pengolahan produk perikanan.

\section{KESIMPULAN}

Semangat dan antusias yang tinggi dari peserta membuat kegiatan berjalan lancar dan sukses, dimana peningkatan pengetahuan peserta terhadap mie kaya nutrisi dan produk olahan perikanan mencapai $100 \%$. Dengan demikian, para peserta telah dapat menciptakan pangan yang kaya nutrisi selain untuk meningkatkan imunitas tubuh, juga dapat meningkatkan pendapatan perekonomian keluarga.

\section{UCAPAN TERIMA KASIH}

Terimakasih kepada LPPM Universitas Riau yang telah memberi bantuan dana kegiatan pengabdian kepada masyarakat ini melalui dana DIPA Universitas Riau tahun 2020.

\section{DAFTAR PUSTAKA}

Domiszewski, Z., G. Bienkiewicz., dan D. Plust. 2011. Effects of Different Heat Treatments on Lipid Quality of Striped Catfish (Pangasius hypophthalmus), Acta Scientiarum Polonorum, Technol. Aliment, 10 (3):359-373.

Purnawijayanti. 2009. Mie Sehat (Cara Pembuatan, Resep-resep Olahan dan Peluang Bisnis). Kanisius, Yogyakarta.

Ridwan, M. 2019. Pengaruh Penambahan Pewarna Alami Pada Mie Basah Ikan Patin (Pangasius Hypophthalmus) terhadap Penerimaan Konsumen. Skripsi. Jurusan Teknologi Hasil Perikanan Fakultas Perikanan dan Kelautan, Universitas Riau, Pekanbaru.

Viji, P., S. Tanuja., G. Ninan., K.V. Lalitha., A.A. Zynudheen., P.K. Binsi., dan T. K. Srinivasagopal. 2015. Biochemical, Textural, Microbiological and Sensory Attributes of Gutted and Ungutted Sutchi Catfish (Pangasianodon hypophthalmus) stored in ice. J Food Sci. Technol, 52(6), 3312-3321. 